\title{
Influence of light quality and gassing on the vertical migration of diatoms inhabiting the Wadden Sea
}

Received: 23 January 2004 / Revised: 7 June 2004 / Accepted: 9 June 2004 / Published online: 3 August 2004

(C) Springer-Verlag and AWI 2004

\begin{abstract}
Diatoms inhabiting the Wadden Sea show a rhythmic migration pattern, which is superimposed by the tidal rhythm. In addition to light intensity, light quality has a pronounced influence on the upward-directed migration, thus giving some information on the nature of the relevant photoreceptors. Maximum diatom migration occurred when sediment surfaces were illuminated with blue light. The cell densities in blue light exceeded those of white light control experiments 1.8 -fold. Furthermore, we registered a minor peak in the red light region, which reached approximately $60 \%$ of the white light controls. Cryptochrome and/or phototropin may thus be involved and act as photoreceptors for the vertical migration pattern. Flushing sediment surfaces of freshly mixed Wadden Sea sediments with air, $\mathrm{O}_{2}, \mathrm{CO}_{2}$ or $\mathrm{N}_{2}$ did not show a significant influence of $\mathrm{O}_{2}$ on the upward migration. The disappearance of diatoms from sediment surfaces which were flushed with $\mathrm{CO}_{2}$ is most probably caused by the acidification of the sediment bed.
\end{abstract}

Keywords Bacillariophyceae · Diatoms · Photoreceptors · Vertical migration · Wadden Sea sediments

\section{Introduction}

Most motile diatoms show an endogenous and rhythmic migration pattern (autonomous reversal rhythm): they

Communicated by E. Rachor

K. Wenderoth $(\bullet)$

FB Biologie/Botanik, AG Zellbiologie, FB Biologie,

Philipps Universität Marburg,

Karl-von-Frisch-Strasse, Lahnberge, 35032 Marburg/Lahn,

Germany

e-mail: wenderot@staff.uni-marburg.de

Tel.: +49-6421-2822059

Fax: +49-6421-2822057

E. Rhiel

AG Geomikrobiologie, ICBM,

Carl von Ossietzky Universität Oldenburg,

Carl von Ossietzky Strasse 9-11, 26125 Oldenburg, Germany move back and forth and reverse direction after defined periods of time. Internal and external stimuli modify this migratory behaviour so that it generally becomes visible as a positive or a negative reaction, i.e. migration towards or away from a stimulus (e.g. Wenderoth and IWF 1983). The threshold values which have to be exceeded or fallen below are species-specific (Nultsch 1956; Cohn and Weitzell 1996). Of major importance in diatoms (as photosynthesizing organisms) are light-regulated migratory reactions, i.e. the perception of the direction of the incident light (photo-topotaxis), the reaction induced by a sudden change or a strong gradient in light intensity (photo-phobotaxis) and the influence of light on the speed of movement (photokinesis). The direction of the incident light is perceived by blue light receptors (Nultsch 1971), and blue light receptors and also, in some species, receptors absorbing red light act in photo-phobotaxis (Wenderoth 1979). During photo-topotactic and photo-phobotactic responses, the endogenous rhythmic reversal becomes modified by comparative measurements at both poles of the cell (Wenderoth 1975; Wenderoth and IWF 1984). The relevant receptors for photokinesis, which show maxima in the blue and red light region of spectrum of the visible light, are most probably pigments functioning in photosynthesis (Nultsch 1971). Aerotaxis is one of the non-lightregulated migratory reactions and describes the influence of air on migratory behaviour, generally resulting in either moving towards or away from higher oxygen concentrations (Hopkins 1966; Nultsch 1956).

Most sediment-inhabiting diatoms show a rhythmic vertical migratory behaviour: generally they migrate upward onto the sediment surface with the onset of light, and downward into the sediment bed with incoming tides or when light intensity decreases. As the migratory behaviour persists even under continuous illumination and in complete darkness, an endogenous rhythm seems to be involved (e.g. Harper 1969; Happey-Wood and Jones 1988). In addition to the endogenous rhythm, light intensity and salinity are shown to have a great impact on the vertical migration (Paterson 1986; Sauer et al. 2002). The impacts of light quality and of the availability or lack of air or defined gases have not been investigated in de- 
tail. The only data available for diatoms inhabiting the Wadden Sea which deals with these topics are given by Hopkins (1966) for Surirella gemma, syn.: Petrodictyon gemma (Ehr.) D.G. Mann. Maximum cell densities were found when the samples were illuminated with blue light. The filters used in these experiments, however, showed rather large half band widths. The author furthermore found the highest numbers of surfacing cells in the absence of light and air, and the lowest numbers in the presence of both of these factors.

The current work focuses on these topics and tries to answer the question whether diatom populations consisting of many species and taken from natural Wadden Sea sediments show the same responses towards light quality and the availability of specified gases. Diatom populations were taken from intertidal sediments and cultured under almost natural conditions in a laboratory tidal micro-ecosystem prior to the experiments in which the quality of light or the availability of air was altered.

\section{Methods}

Field site and sampling conditions

Field samples were collected from muddy intertidal sediments located on the North Sea shore near the harbour of Dangast (Germany) on 23 August 2001. Low tides were at 05:00 and 17:08 and high tides at 11:01 and 23:30 hours. Sampling was performed as described by Sauer et al. (2002). After transfer to the laboratory, the Petri dishes were stored at $20^{\circ} \mathrm{C}$ under a $12: 12 \mathrm{~h}$ low white light: dark regime (photon-fluence rate $10 \mu \mathrm{mol} \mathrm{m} \mathrm{m}^{-2} \mathrm{~s}^{-1}$ during the light phase provided by Osram L36/32 Luminux Warmton fluorescence tubes in combination with Osram L36/16 Tageslicht fluorescence tubes) in a laboratory tidal micro-ecosystem for up to 21 days. The micro-ecosystem is shown in Fig. 1. Tidal cover and tidal exposure were reached by a motor-driven rake which moved up and down in a tank filled with 201 artificial seawater medium at defined times. The Petri dishes were placed onto the rake and notched so that the water could drain off completely. The rake moved approximately $2-5 \mathrm{~cm}$ into the water. Thus, the device only simulated covered and uncovered conditions of the sediments and did not reduce the light quantity significantly. Low tide occurred at 08:30 and 14:30, respectively, and high tide at 20:30 and 02:30 hours. Both were reached within a time period of 6 min. Tropic Marin (Dr. Biener $\mathrm{GmbH}$, Wartenberg, Germany) was used as a salt source for the artificial seawater medium whose salinity was adjusted to $35 \mathrm{ppm}$.

\section{Experimental setup}

Experiments were set up within the first hour after onset of irradiation, which was at 09:00 hours. Sediment samples were homogeneously mixed with acid-cleaned sea sand (Merck, Darmstadt, Germany) which was pre-wetted with artificial seawater. The slurry was filled into small Petri dishes of $30 \mathrm{~mm}$ diameter $(7 \mathrm{~g}$ sediment per Petri dish) and incubated as described below.

\section{Light quality experiments}

In a first set of experiments ( $n=3$ for each wavelength investigated), the Petri dishes were kept at $18^{\circ} \mathrm{C}$ for $3 \mathrm{~h}$ either in complete darkness or exposed to light wavelengths of 410,424, 432, 443, 452, 461, 476, 487, 493, 503, 512, 525, 537, 545, 564, 578, 585, $595,615,627,646,661,669,680,700$ or $715 \mathrm{~nm}$ (see Fig. 2) which were generated by placing interference filters (Schott, Mainz, light $\left(10 \mu \mathrm{mol} \mathrm{m} \mathrm{m}^{-2} \mathrm{~s}^{-1}\right)$
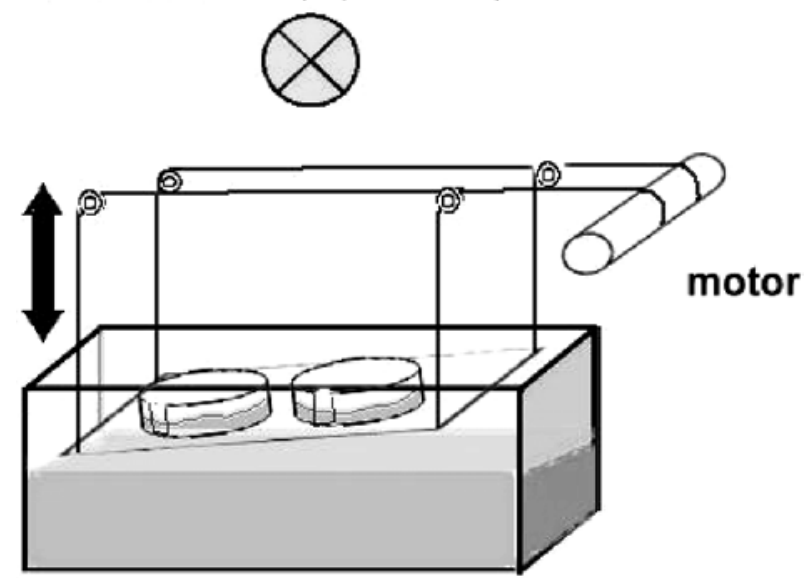

Fig. 1 Schematic drawing of the laboratory tidal micro-ecosystem. The tank was filled with 201 artificial seawater. Petri dishes containing Wadden Sea sediment were placed onto a rake which was moved down into or out of the seawater by a timer-controlled motor. The Petri dishes were notched so that the water could drain off completely. Low intensity white light with a photon-fluence rate of $10 \mu \mathrm{mol} \mathrm{m} \mathrm{m}^{-1}$ was provided from above

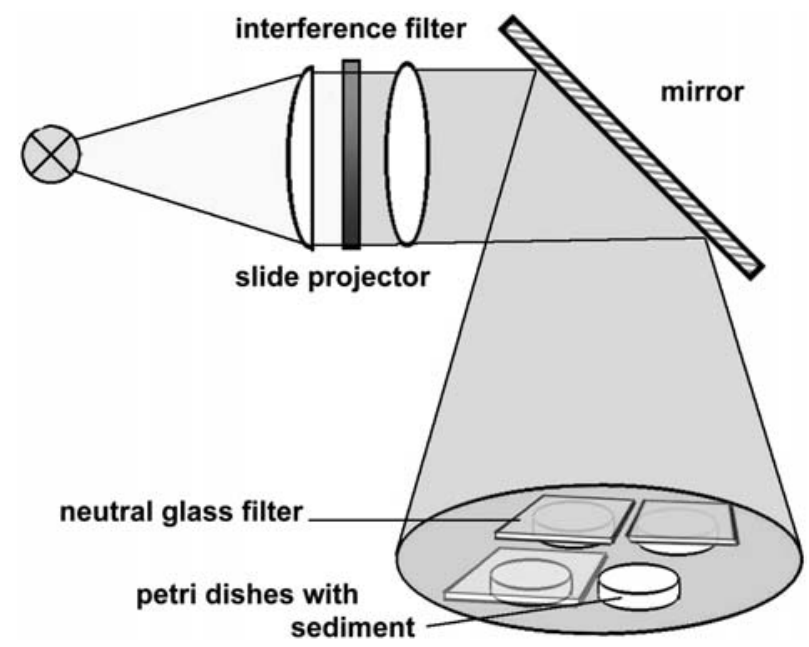

Fig. 2 Experimental setup of the light quality experiments. Interference filters of wavelengths ranging from 410 to $715 \mathrm{~nm}$ were placed in the slide stages of projectors. The photon-fluence rates were adjusted to $0.5,1.0,2.5$ and $5.0 \mu \mathrm{mol} \mathrm{m} \mathrm{m}^{-2} \mathrm{~s}^{-1}$. Incubation of Petri dishes under white light with a photon-fluence rate of $5.0 \mu \mathrm{mol} \mathrm{m} \mathrm{m}^{-2} \mathrm{~s}^{-1}$ was used as a positive control for upward vertical migration (white Petri dish)

Germany, half band width $10 \mathrm{~nm}$ ) in the slide stages of projectors (Leitz, Wetzlar, Germany). The photon-fluence rates were adjusted to $0.5,1.0,2.5$ and $5.0 \mu \mathrm{mol} \mathrm{m} \mathrm{m}^{-2} \mathrm{~s}^{-1}$, for each wavelength by increasing or reducing the light intensity of the projector and/or placing neutral glass filters (Schott, Mainz, Germany) onto the Petri dishes. Incubation of Petri dishes under white light of $5.0 \mu \mathrm{mol} \mathrm{m}$ $\mathrm{s}^{-1}$ was used as a positive control for upward directed vertical migration. Then, the cell densities of diatoms that had surfaced were documented by epifluorescence light microscopy. 


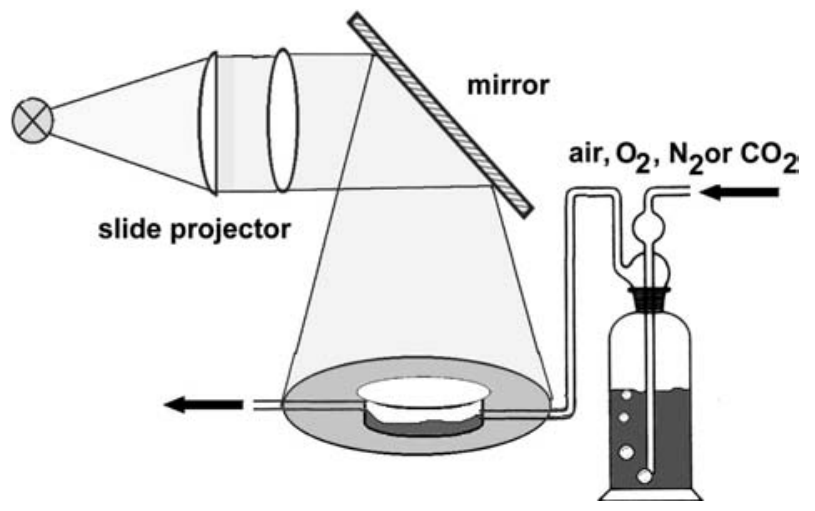

Fig. 3 Experimental setup of the gas flushing experiments. Either air provided by an aquarium pump or $\mathrm{O}_{2}, \mathrm{~N}_{2}, \mathrm{CO}_{2}$ from gas cylinders were pre-wetted by guiding them through a washing flask filled with water prior to flushing. The sediments were poured into Petri dishes and placed without lids in glass chambers with in- and outlet ports for the gases. The glass chambers were kept at $20^{\circ} \mathrm{C}$ for $3 \mathrm{~h}$ and either illuminated with white light of a photon-fluence rate of $200 \mu \mathrm{mol} \mathrm{m} \mathrm{m}^{-2} \mathrm{~s}^{-1}$ or kept in the dark (not shown in this figure)

Gas flushing experiments

The second set of experiments $(n=3)$ focused on the influence/ availability of gases on the upward vertical migration. The experimental setup is shown in Fig. 3. Either air delivered by a small aquarium pump or $\mathrm{O}_{2}, \mathrm{~N}_{2}, \mathrm{CO}_{2}$ from gas cylinders were used. The gases were pre-wetted by guiding them through a washing flask filled with water prior to flushing. The sediments were poured into small Petri dishes and placed without lids in glass chambers with in- and outlet ports for the gases. The glass chambers were kept at $20^{\circ} \mathrm{C}$ for $3 \mathrm{~h}$ and either illuminated with white light of $200 \mu \mathrm{mol}$ $\mathrm{m}^{-2} \mathrm{~s}^{-1}$ intensity or kept in the dark.

\section{Fluorescence microscopy}

Cell densities on the surfaces of large sediment areas within the Petri dishes were examined using epifluorescence light microscopy as described by Sauer et al. (2002). At least 30 pictures were taken per Petri dish and stored as digitized files on a personal computer. The diatoms, i.e. their chlorophyll fluorescence, were counted directly from the pictures on the screen of the computer using the UTHSCSA Image Tool software. At least 100 pictures originating from the three individual experiments were counted and used as a data set for each wavelength, while approx. 1,000 pictures originating from the three individual flushing experiments were evaluated.

Light measurements and statistical analyses

Measurements of the photon-fluence rates and statistical analyses ( $t$ test) were performed as described by Sauer et al. (2002).

\section{Results}

Influence of the light quality

on the upward directed migration

Diatoms from Wadden Sea sediment samples were homogeneously mixed with pre-wetted sea sand, filled into Petri dishes and allowed to surface for $3 \mathrm{~h}$ in the dark,

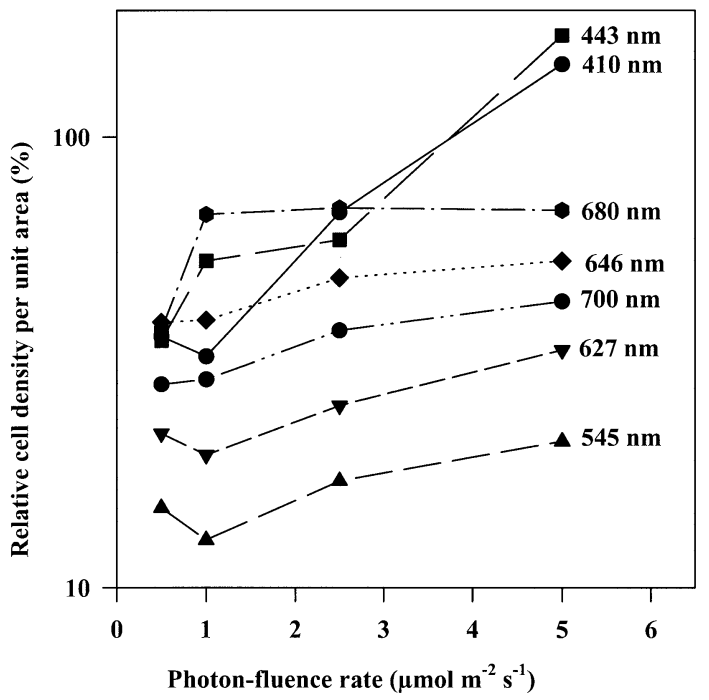

Fig. 4 Photon-fluence rate response curves of some representative wavelengths. The wavelengths are indicated to the right of each curve. The relative cell density per unit area is expressed as a percentage of the white light control

under low intensity white light or under defined light qualities. The number of cells surfacing in white light was used as an internal control for each experiment and its value was set to $100 \%$.

In order to rule out saturation with light in our experiments, the sediment samples were illuminated with the different light qualities at rather low photon-fluence rates of $0.5,1.0,2.5$ and $5.0 \mu \mathrm{mol} \mathrm{m} \mathrm{m}^{-2} \mathrm{~s}^{-1}$. Photon-fluence rate response curves were generated for each of the wavelengths applied. The photon-fluence rate response curves of some light qualities are given in Fig. 4 and show that the curves were almost linear only at photon-fluence rates higher than $1.0 \mu \mathrm{mol} \mathrm{m} \mathrm{m}^{-2} \mathrm{~s}^{-1}$. Therefore, for registering the action spectrum curves, only those data were used which were obtained at photon-fluence rates of $5.0 \mu \mathrm{mol} \mathrm{m} \mathrm{m}^{-2} \mathrm{~s}^{-1}$ for the different light qualities.

The three experiments gave rise to similar results which are shown in the representative action spectrum curve of Fig. 5. Maximal cell densities on the sediment surface were registered when illuminating with blue light of $443 \mathrm{~nm}$. The values exceeded those of the white light controls approx. 1.8-fold. Irradiation with green light of $530-540 \mathrm{~nm}$ led to a strong decrease in the number of cells that surfaced (approx. 20\% of the white light controls). Red light of $680 \mathrm{~nm}$ had, in comparison to green light, a positive effect, although less pronounced than blue light, and caused values in cell density of $60 \%$ of the white light controls. Illuminating the sediments with light qualities of $476 \mathrm{~nm}, 512 \mathrm{~nm}, 595 \mathrm{~nm}$ and 627-646 nm resulted in the appearance of minor shoulders and maxima. $T$ test analyses conducted with the data sets obtained for $443 \mathrm{~nm}, 537 \mathrm{~nm}$ and $680 \mathrm{~nm}$ confirmed that the values were statistically significant $(P<0.00012)$. 


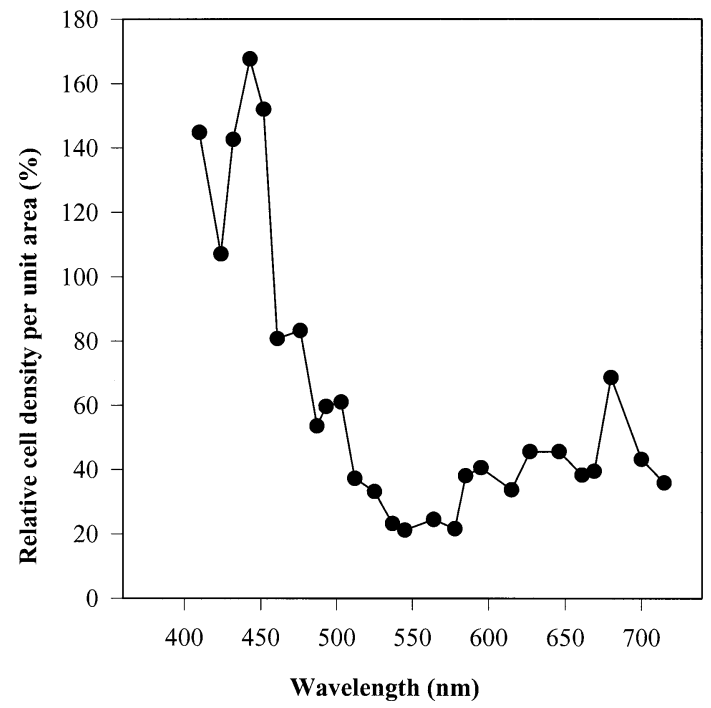

Fig. 5 Action spectrum of the upward vertical migration of diatoms inhabiting the Wadden Sea obtained for a photon-fluence rate of $5 \mu \mathrm{mol} \mathrm{m} \mathrm{m}^{-1}$. The relative cell density per unit area is expressed as a percentage of the white light control

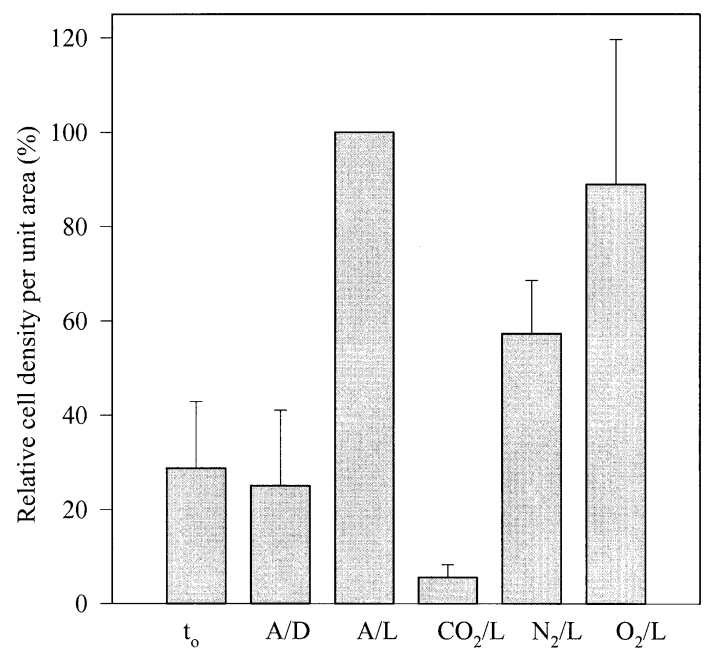

Fig. 6 Histogram showing the influence of flushing the sediment surfaces with either air $(A)$ or the gasses oxygen $\left(\mathrm{O}_{2}\right)$, nitrogen $\left(\mathrm{N}_{2}\right)$ or carbon dioxide $\left(\mathrm{CO}_{2}\right)$ either in the light $(L)$ or dark $(D)$. The relative cell density per unit area is expressed as a \% $( \pm \mathrm{SD})$ of the control $(A / L)$ which was set to $100 \%$ in each experiment and thus is shown without SD. $t_{o}$ Cell density immediately after mixing the sediment samples

Influence of flushing the sediments with $\mathrm{O} 2, \mathrm{CO} 2$, $\mathrm{N} 2$ and air

The results of the flushing experiments are compiled in Fig. 6. Flushing the sediment surface with air in the absence of light (A/D) did not led to an increase in cell density, and gave rise to values similar to those measured immediately after pouring the sediment samples into the Petri dishes $\left(t_{0}\right)$. Gassing with air in the presence of light $(\mathrm{A} / \mathrm{L})$ led to a three- to four-fold increase in cell density.
Gassing with $\mathrm{O}_{2}$ in the presence of light $\left(\mathrm{O}_{2} / \mathrm{L}\right)$ showed a minor but not significant $(P>0.2)$ positive effect on the upward migration when compared to gassing experiments with air in the presence of light (A/L). The amount of cells surfacing either in the presence of air and light $(\mathrm{A} / \mathrm{L})$ or in the presence of $\mathrm{O}_{2}$ and light $\left(\mathrm{O}_{2} / \mathrm{L}\right)$, however, were significantly higher than the value found when gassing with nitrogen in the presence of light $\left(\mathrm{N}_{2} / \mathrm{L}\right.$ ) (both approx. $P=0.04)$. In contrast, flushing with $\mathrm{CO}_{2}$ in the presence of light $\left(\mathrm{CO}_{2} / \mathrm{L}\right)$ led to a significant reduction in the number of cells on the surface $(P<0.0001)$ and even fell below values measured for the $t_{0}$ and dark controls. Approximately $12 \%$ of the cell density of the white light control (L/L) was measured for gassing with $\mathrm{CO}_{2}$ in the presence of light.

\section{Discussion}

Light quality has a pronounced effect on the upward migration of diatom communities. Maximum cell densities were found when the sediment samples were illuminated with blue light of $443 \mathrm{~nm}$. Hopkins (1966) investigated the upward migration of Surirella gemma and found that light of 450-500 nm was most effective and resulted in maximum community densities, exceeding those of the daylight controls approx. 1.4-fold. This value is similar to the 1.8-fold higher value we measured for the entire population of diatoms inhabiting the Wadden Sea, compared to white light controls. Furthermore, wavelengths below $440 \mathrm{~nm}$ and above $550 \mathrm{~nm}$ resulted in fewer surfacing cells compared to white light. The lowest cell densities were registered at 420 and $620 \mathrm{~nm}$. The filters used in these experiments, however, showed rather large half band widths and this might explain why the minor peaks and shoulders which we registered were not visible in Hopkins' (1966) investigation. Photo-topotaxis seems to play a major role in the vertical migration of diatoms inhabiting the Wadden Sea in their natural habitat. The relevant photoreceptors are cryptochromes and phototropines: both are flavoproteins and sense UV-A and blue light. Genes encoding cryptochromes and phototropins have been cloned and sequenced from a wide variety of plants (e.g. Batschauer 1998). The function and location of the corresponding gene products within the cell have been the subject of recent investigations. In higher plants, cryptochromes are involved in the regulation of circadian rhythms, the inhibition of hypocotyl elongation, cotyledon expansion and the transition to flowering, while phototropins are involved in phototropism, chloroplast migration and stomatal opening (Malakhov and Bowler 2001; Briggs and Christie 2002). Whole genome sequencing, meanwhile, revealed the presence of genes encoding cryptochromes, phototropins and phytochromes in the centric diatom Thalassiosira pseudonana (Bowler et al. 2003). Furthermore, a cryptochrome gene (CRY1) has been cloned and sequenced from the pennate diatom Phaeodactylum tricornutum (Bowler et al. 2003). 
In addition, we registered that red light of $680 \mathrm{~nm}$ showed a weak positive effect on the upward migration and resulted in cell density values of approx. $68 \%$ of the white light controls. This is in contrast to Bowler et al. (2003), who found that cells of P. tricornutum moved away from red light. The effect might be caused by phytochromes, photoreceptors which absorb red and far red light. Phytochromes have serine/threonine protein kinase activity and become translocated from the cytoplasm to the nucleus in a light-regulated manner. Most of the phytochrome-interacting proteins which have been identified are localized in the nucleus and act within a signal transduction pathway which finally leads to the induction or repression of components localised in the cytoplasm or nuclear (Malakhov and Bowler 2001). Currently, this kind of signal cascade, involved in phototactic movement, is unknown in diatoms. Alternatively, pigments functioning in photosynthesis might be responsible for the minor peak at $680 \mathrm{~nm}$. According to Nultsch (1971), photokinesis directly depends on photosynthesis, and enhancement of the overall photosynthetic activity in red light might lead to enhanced migratory activity. Chlorophylls and carotinoids would function as relevant photoreceptors in this case. Currently, almost no data are available on how the spectral quality of light changes within the uppermost millimetres of Wadden Sea sediment. Kühl and Fenchel (2000) investigated the bio-optical characteristics in an artificial cyanobacterial mat and found that visible light was attenuated more than 100 times more strongly than near infrared light. Furthermore, Underwood (2002) found that the photon-fluence rate dropped from approx. $2500 \mu \mathrm{mol} \mathrm{m}{ }^{-2} \mathrm{~s}^{-1}$ measured at the sediment surface to values less than $100 \mu \mathrm{mol} \mathrm{m}^{-2} \mathrm{~s}^{-1}$ at a depth of $200 \mu \mathrm{m}$ in intertidal silt. Thus, extreme gradients in light are highly likely to occur within the uppermost sediment layers, causing photo-phobotactic responses. The ecological relevance of this photo-phobotactic response might be to stay in the vertical horizon which is best suited for photosynthesis. Phytochromes might play a role in this response and cannot currently be ruled out as photoreceptors functioning in the vertical migratory behaviour of diatoms inhabiting the Wadden Sea.

Flushing the sediment surfaces with $\mathrm{O}_{2}$ did not give rise to a clear positive or negative result. We registered, within the frame of error, almost similar cell densities when gassing with air or oxygen. Thus, we conclude that aerotaxis does not play a major role in the vertical migration pattern under natural conditions. The effect caused by $\mathrm{CO}_{2}$ can be explained by lowered $\mathrm{pH}$ values, as the $\mathrm{pH}$ value of the water in the washing flasks dropped from approx. $\mathrm{pH} 7$ to values of $\mathrm{pH} 4-5$ during flushing with $\mathrm{CO}_{2}$, while almost constant $\mathrm{pH}$ values were measured for the other gases. Humid $\mathrm{CO}_{2}$ thus may lead to lowered sediment $\mathrm{pH}$ values and to an acidification of the uppermost sediment layers. This phenomenon might explain the downward migration and disappearance of diatoms from sediment surfaces on rainy days, as rainwater generally shows $\mathrm{pH}$ values in the range of $\mathrm{pH} 4$ to 5 , similar to those we measured when flushing with $\mathrm{CO}_{2}$.

Acknowledgements We wish to thank Michael Pilzen for his help in evaluating the digitized pictures and Prof. Dr. Paul Galland and Prof. Dr. Uwe G. Maier (both from the Philipps University, Marburg) for technical support. The authors declare that the experiments comply with the current laws of Germany.

\section{References}

Batschauer A (1998) Photoreceptors of higher plants. Planta 206:479-492

Briggs WR, Christie JM (2002) Phototropins1 and 2: versatile plant blue-light receptors. Trends Plant Sci 7:204-210

Bowler C, Mangongna M, Falciatore A, de Martino A (2003) Photoreceptors in marine diatoms. In: Batschauer A, Galland P, Dörnemann D, Hughes J, Forreiter C, Zeidler M (eds) International plant photobiology meeting, Marburg. Book of abstracts, p36

Cohn SA, Weitzell RE (1996) Ecological considerations of diatom cell motility. I. Characterization of motility and adhesion in four diatom species. J Phycol 32:928-939

Happey-Wood CM, Jones P (1988) Rhythms of vertical migration and motility in intertidal benthic diatoms with particular reference to Pleurosigma angulatum. Diatom Res 3:85-95

Harper MA (1969) Movement and migration of diatoms on sand grains. Br Phycol J 4:97-103

Hopkins JT (1966) Some light-induced changes in behaviour and cytology of an estuarine mud-flat diatom. In: Bainbridge R (ed) Light as an ecological factor. Symposium of the British Ecology Society 5. Blackwell, Oxford, pp 335-358

Kühl M, Fenchel T (2000) Bio-optical characteristics and the vertical distribution of photosynthetic pigments and photosynthesis in an artificial cyanobacterial mat. Microb Ecol 40:94-103

Malakhov M, Bowler C (2001) Phytochrome and regulation of photosynthetic gene expression. In: Aro E-M, Andersson B (eds) Advances in photosynthesis and respiration, vol 11. Regulation of photosynthesis. Kluwer, Dordrecht, pp 51-66

Nultsch W (1956) Studien über die Phototaxis der Diatomeen. Arch Protistenkd 101:1-68

Nultsch W (1971) Phototactic and photokinetic action spectra of the diatom Nitzschia communis. Photochem Photobiol 14:705-712

Paterson DM (1986) The migratory behaviour of diatom assemblages in a laboratory tidal micro-ecosystem examined by low temperature scanning electron microscopy. Diatom Res 1:227239

Sauer S, Wenderoth K, Maier UG, Rhiel E (2002) Effects of salinity, light and time on the vertical migration of diatom assemblages. Diatom Res 17:189-203

Underwood GJC (2002) Adaptations of tropical marine microphytobenthic assemblages along a gradient of light and nutrient availability in Suva Lagoon, Fiji. Eur J Phycol 37:449-462

Wenderoth K (1975) Untersuchungen der Photo-Phobotaktischen Reaktion einzelner Diatomeenzellen. Dissertation, Philipps Universität Marburg

Wenderoth K (1979) Photophobische Reaktionen von Diatomeen im monochromatischen Licht. Ber Dtsch Bot Ges 92:313-321

Wenderoth K, IWF (1983) Photokinese und photophobische Reaktionen der Kieselalge Navicula peregrina. Film C1388 des IWF Göttingen. Publ Wiss Film, Sekt Biol, Ser 16, Nr 11/C1388:1-13

Wenderoth K, IWF (1984) Reaktion der Kieselalge Navicula peregrina auf Belichtung verschiedener Zellabschnitte. Film C1466 des IWF Göttingen. Publ Wiss Film, Sekt Biol, Ser 16, Nr 21/C1466:1-13 